\title{
5. Talking about solidarity ... it sounds like a whisper: solidarity in law and public policies ${ }^{1}$
}

\section{Veronica Federico}

\subsection{INTRODUCTION}

Solidarity is etymologically rooted in a legal principle, the obligatio in solidum that in ancient Roman times meant that, in contracts with several co-obligants, each of them was liable for the full payment or performance. In other words, something like 'one for all, all for one'. Over the course of many centuries, this legal principle has moved from Roman contract law to the constitutional realm, underpinning the principle of collective responsibility and "allowing individuals to think on a collective dimension" (Supiot, 2015: 7; see also Blais, 2007; Rodotà, 2014). By recognising the revolutionary principle of solidarity (named fraternité in that context) as the socio-legal marker of a nation state, the newly created national communities of the eighteenth and nineteenth centuries transformed solidarity into a proper and binding legal standard. Since then, solidarity has become a general principle of law, first at national level, and then, through the action of the European Court of Justice and the principles endorsed by the EU's Charter of Fundamental Rights, at the European level.

As a general principle of law enshrined in European member state constitutions, solidarity defines the interdependences of the diverse elements of the social fabric, bridging the different divides that characterise contemporary societies in a tight weft of reciprocal exchanges. Recent crises have re-opened a number of those divides both within European member states (between the rich and the poor, the native and the foreigner, the employed and the unemployed, etc.) and among member states themselves, increasing the need for solidarity in both material and symbolic terms. Inequality has increased among and within countries; poverty is back on the political agenda and in the spotlight of media debate; inequality has generated an escalation in xenophobia and the tightening of immigration laws; and it has polarised political debate. Crisis-driven reforms (welfare system, 
labour market, immigration and asylum laws, to quote the more relevant for our analysis) have marked all countries examined here (Denmark, France, Germany, Greece, Italy, Poland, Switzerland, and the UK), although to very different extents.

Against this backdrop, the purpose of the chapter is to explore to what extent solidarity as a fundamental principle in law and policy-making, as well as in judicial review and constitutional litigation, has proved to be a meaningful legal paradigm during the years following the 2008 financial crisis. This can be measured by the capacity of stimulating adequate normative responses to material and political needs generated and increased by the crisis, and in mitigating at least a portion of the most severe retrenchment measures.

Prima facie, we could be tempted to claim that solidarity simply came up short. In fact, the failure to meet European citizens' expectations in terms of the capacity to both provide adequate responses to basic needs, and to craft new, alternative visions of future European societies, is evident. And yet, the story is more complicated than this basic statement. The political, social and academic debates of the past decade have revealed the latent potency of existing legal, institutional, social principles and mechanisms that could prove useful when re-thinking and re-conceptualising social, political and legal institutions at national and supranational level in postcrisis times. New actors have emerged over the years (movements, groups, parties, etc.), and others (such as courts) have sometimes revealed themselves to be more forward-thinking than expected. A more sophisticated discussion on the presence of solidarity among the funding principles of contemporary European constitutional systems will unveil specific policy traits and legal systems and their social responses. These are crucial for reflecting on whether - following Habermas' (2013) call - a viable path is still available towards a more pervasive European (i.e. transnational) solidarity which will overcome politically the heavy legacy of the economic crisis that itself threatened the very legitimacy of the EU. That is to say, whether solidarity as a legal principle still has something to offer to postcrisis societies.

In this chapter, we will reflect on the significance of the formal inclusion of solidarity in the constitutional texts of Denmark, France, Germany, Greece, Italy, Poland, Switzerland, and the UK, and in the EU treaties. Secondly, we will discuss the most relevant dimensions of solidarity in the different jurisdictions. Finally, through the comparative scrutiny of legal and policy regulations of the unemployment, disability and immigration/ asylum sectors, and of the impact of the financial crisis, we will examine whether solidarity has proved to be a robust enough shield to safeguard alternative visons for European societies. 


\subsection{TALKING ABOUT SOLIDARITY ... IN THE CONSTITUTIONS}

Since the end of the Second World War, solidarity has been fully entrenched in constitutional texts in Europe (De Búrca and Weiler, 2011; Tuori, 2015), enshrined in a new model of constitutions grounded in the value of the person, human dignity and fundamental rights. In these constitutions, rights and liberties are conceived in a solidarity frame; therefore the respect for and guarantee of those rights and liberties has to be intrinsically combined with the meta-principle of social solidarity (Cippitani, 2010: 34-7). It is a highly relevant legal innovation. Despite the fact that in Western democracies rights and liberties are based on the individual (Bobbio, 1990), the solidarity principle they are framed in transforms them into the cement holding political communities together; that is to say, solidarity contributes to contemporary democracies' communitybuilding (Brunkhorst, 2005). The interweaving of rights and solidarity becomes clear, for example, in Art. 25(4) of the Greek constitution ("The State has the right to claim of all citizens to fulfil the duty of social and national solidarity") and in Art. 2 of the 1948 Italian Constitution ("The Republic recognises and guarantees the inviolable human rights, be it as an individual or in social groups expressing their personality, and it ensures the performance of the unalterable duty to political, economic, and social solidarity"). Inviolable human rights are therefore intertwined with the "unalterable duty to [. . . ] social solidarity".

At the EU level, on 9 May 1950, the French Foreign Minister Robert Schuman, proposing the creation of a European Coal and Steel Community, declared that "Europe will not be made all at once, or according to a single plan. It will be built through concrete achievements which first create a de facto solidarity" (Ross, 2010: 45). Solidarity has featured in the EU landscape since the very beginning, despite a number of ambiguities, and "the Lisbon treaty confirms [its] centrality in the EU's future constitutional arrangements" (Ross, 2010: 45).

A closer look at the constitutions reveals that solidarity is explicitly named in the constitutional texts of France, Greece, Italy and Poland; in France, Poland and Switzerland it is also evoked (or only) in the preamble to the constitution, and in the remaining three cases (Denmark, Germany and the UK) it has to be inferred by a systematic interpretation of contiguous legal principles, such as equality, human dignity, and so on. In the EU treaties, a number of articles explicitly refer to solidarity: from Art. 3 of the TEU, enunciating the objectives of the Union (the Union "shall promote economic, social and territorial cohesion, and solidarity among Member States") to Art. 80 of the TFEU ("The policies of the Union set 
out in this Chapter [V, devoted to EU policies on border checks, asylum and immigration] and their implementation shall be governed by the principle of solidarity and fair sharing of responsibility, including its financial implications, between the Member States" - emphasis added), and Arts 122 and 194 of the TFEU which establish a principle of solidarity in the field of economic policy and in particular with reference to energy policy: "Without prejudice to any other procedures provided for in the Treaties, the Council, on a proposal from the Commission, may decide, in a spirit of solidarity between Member States, upon the measures appropriate to the economic situation, in particular if severe difficulties arise in the supply of certain products, notably in the area of energy."

Solidarity, therefore, is part of the constitutional DNA of all the countries examined here and of the EU. This entails, first, that the constitutional value attributed to solidarity allows legislators and policy-makers to refer to it as a legitimate source of laws and policies that go far beyond the more typical application of the principle of solidarity (the welfare system), spanning many areas, from housing policies to family law; from fiscal measures and tax law to labour law; from international cooperation to energy legislation; from the promotion of volunteering and civil society to freedom of association (Federico, 2018). Second, should any legal or policy act be in breach of it, as has happened during the financial crisis, the constitutional entrenchment of solidarity makes it easier for judges, especially constitutional judges, to refer to it as an insurmountable constitutional paradigm. Indeed, both the Italian Constitutional Court and the French Constitutional Council have been prone to refer to solidarity as a tool to mitigate measures that might have a negative impact on vulnerable people's dignity. The French Constitutional Council has referred to the notion of solidarity many times with a plurality of meanings. The Constitutional Council uses the terms mécanisme (mechanism) of solidarity, principe de solidarité (principle of solidarity), exigence de solidarité (solidarity requirement), objectif de solidarité (solidarity objective), sometimes relying on several of them in the same decision. It is therefore not a monovalent concept. Obviously, the privileged applications of these notions lie in the domain of social systems, spanning the routes that individuals make across their lives, for example in and out of the labour market. Similarly, the Italian Constitutional Court often uses solidarity in very diverse fields. Recently, in a case concerning the right to education of pupils with disabilities (CC decision n.257 of 16 December 2016), the Court went much further than simply mitigating austerity measures. It argued that, when a core of absolute, unswerving guarantees for vulnerable people is at stake, the very balancing of interests (which is the essence of constitutional courts' usual reasoning) becomes pointless. The duty of 
social solidarity simply prevails. What emerges here is a very powerful interpretative innovation that might open the door to more pervasive applications of the solidarity principle in the future.

Noticeably, in Greece, constitutional case-law is more ambivalent than in other countries and it brings to the forefront another very important but highly contested - entailment of the principle of solidarity: sacrificing the interests of determined categories in the name of the survival of the whole nation. During the crisis, the Greek judiciary has interpreted solidarity as a constitutional paradigm both to mitigate some crisis-driven reforms (in this case solidarity assumes the function of a shield, protecting people's fundamental rights and access to a decent living), and to enforce other austerity laws (in this case solidarity assumes the value of the community's higher common interest). In fact, on the one hand the Council of State (case 668/2012) maintained that the reductions in public wages, pensions and other benefits were justified by the stronger public interest of improving the state's economy and financial situation (moreover the measures guaranteed the common interest of the member state of the Eurozone, which made this a sort of reinforced public interest). On the other hand, the Court of Auditors (Proceedings of the 2nd special session of the plenary, 27 February 2013) ascertained that the discretion of legislators to adopt restrictive measures to decrease public spending should not jeopardise adequate living conditions (recognised by Articles 2 and 4(5) of the Constitution), and should ensure a fair distribution of the crisisburden on citizens in the name of the principle of proportionality (Art. 25(1)) and of the state's right to require social and national solidarity as a duty of all citizens.

This is particularly interesting from our perspective: the apparent ambiguity of Greek court decisions reveals a crucial element of the notion of solidarity mentioned in the introduction. If solidarity is to be considered as a status of intersubjectivity, in which people are bound together, whether by a shared identity or by the facts of their actual interest, into mutual relationships of interdependence and reciprocal aid, the two dimensions of solidarity that emerge in Greek case-law are both crucial: fundamental rights that grant human dignity on the one hand, and the very existence of the community, which may require the sacrifice of individual interests and benefits, on the other. Beyond the political and social evaluation of the Greek austerity measures, what is relevant here is that this extremely critical situation revealed the notion of solidarity as an interconnection between rights and duties. And it is this interconnectivity that integrates the individual into a community of citizens (Apostoli, 2012: 10-11).

At the EU level, until recently, the Court of Justice had developed caselaw which incrementally broadened EU citizens' rights to social benefits 
in the name of a certain degree of financial solidarity among member states (Lanceiro, 2017: 4). Recently, however, the Dano and Alimanovic judgments represent a significant change and they contribute to the consolidation of a restrictive trend in interpreting solidarity-based measures, "casting an increasingly tolerant eye upon national measures restricting the access to social benefits by mobile EU citizens [. . .]. By so doing, it sacrificed the expansive logic of Union citizenship as a fundamental status of European citizens" (Giubboni and Costamagna, 2017). Accentuating the protection of member states' interests, the Court sacrifices a broad, pervasive understanding of solidarity between member states.

\subsection{TALKING ABOUT SOLIDARITY ... ITS DIMENSIONS}

When solidarity "defines a perimeter of mutual assistance which includes some people and excludes others" (Supiot, 2015: 15), citizenship - which is the marker of this perimeter - means that the legal bond between the individual and the state creates a relationship of mutual responsibility that does not simply concern a bi-directional vertical dimension between the state and its citizens, but also a bi-directional horizontal dimension, i.e. between fellow-citizens. Every citizen is responsible for the promotion and guarantee of fellow citizens' rights and needs (Apostoli, 2012: 143). Moreover, in decentralised states, solidarity acquires a further, crucial aspect: the territorial dimension, i.e. the principle of federal solidarity. "The general idea is that governments forming a federation do not merely calculate their actions to be to their own benefit. By forming a federation, partners intend to work collectively for the common good of a shared citizenry. Each government - be it federal, provincial or territorial - owes special duties to the other common members of the federation that they do not necessarily owe to foreign states (or that are not owed with the same degree of intensity) precisely because they belong to a common body politic" (Cyr, 2014: 31). These three dimensions (vertical, horizontal and territorial) are all interconnected, and they assume a slightly different connotation at the EU level. ${ }^{2}$

The most relevant element of solidarity's vertical dimension in every country is the welfare system (Ferrera, 2005). European welfare states diverge in the extent and form of institutionalising solidarity: from the Danish social democratic Nordic welfare model (Esping-Andersen, 1990), where there is a strong state that builds on the principles of universalism by providing tax-financed benefits and services, to the Italian residual welfare state in the broader category of the conservative-corporatist model (or 
Ferrera's (1996) Southern group model), where social services are provided to people who are unable to help themselves; from the Swiss liberal welfare with a moderate decommodification but with a high generosity index, close to the one in Sweden (Scruggs and Allan, 2006: 67) to the Greek pre-crisis corporatist model based on moderation and the elimination of the most dramatic inequalities through redistribution policies; from the Polish social model which blends elements of liberalism in a conservative and corporate tradition inherited from the period between the wars (Esping-Andresen, 1990) to the French corporatist regime reflecting, for the most part, the Bismarckian tradition of earning-related benefits (Serre and Palier, 2004); from the British universalism based on the Beveridge model (Taylor-Gooby, 2013) to the typical conservative welfare regime in Germany (EspingAndersen, 1990). Whatever the type of welfare regime, however, all presume an unequal distribution of resources and wealth, and the specific function of solidarity is to bridge these inequalities through redistribution policies. Solidarity that is embodied in welfare systems on the one hand promotes human dignity through the enforcement of fundamental rights, and, in this sense, the welfare state represents the institutional form of social solidarity generated in constitutional principles and specified in codified entitlements to social policies. On the other hand, solidarity promotes social cohesion through the binding force of the interconnectivity between rights and duties. Indeed, the welfare state as a set of redistributive policies has been a key tool in the promotion of national identity, and therefore as a way to create solidarity among citizens, "bounding for bonding" (Ferrera, 2005: 44). In fact, citizens allow a redistribution of their resources to happen as long as they perceive each other as members of the same group or nation. As we will highlight later on, the crucial issue, then, becomes the boundaries of welfare, i.e. where to draw the perimeter of solidarity.

The second dimension is the horizontal one. "The concrete enforcement of solidarity in its vertical dimension (from the State and the institutions towards individuals) is tightly connected to the functioning of the guiding principle of subsidiarity [...] as subsidiarity presupposes the subsidium, which is the duty of participation and support 'top down' by virtue of social cohesion" (Apostoli, 2012: 61). Subsidiarity opens the public sphere to citizens' participation and free engagement in the fulfilment of fundamental rights and in services delivery, connecting the vertical and horizontal dimensions.

Civil society participates in enforcing the rights and may even go further by directing its energy towards expanding and enriching the quality and quantity of those rights (Onida, 2003: 116). In other words, if rights cannot be fully and directly enforced by the state, either because of economic restrictions (as may be the case during a crisis) or because of 
political opportunity reasons, the state may activate the citizens' duty of solidarity through legislation promoting private intervention.

Civil society activism may be favoured by specific legislation and measures promoting the third sector (as has been the case of Italian law n.266 of 1991 or the Polish Law on Public Benefit Activity and Volunteerism of 23 April 2003), and it has provided valuable solidarity responses during the crisis, as the Greek case clearly describes (Mexi, 2018). But the opening to this horizontal dimension may also acquire more ambiguous political aspects, as was the case in the UK, with David Cameron's 'Big Society' policy, where subsidiarity became the excuse for retrenchments and cuts (Montgomery and Baglioni, 2018).

Moreover, the horizontal dimension of solidarity finds its most evident and most widespread expression in volunteerism. Indeed, in all our case-studies the social value of solidarity is tightly intertwined with volunteering. Being engaged in civil society activities, donating time, competencies and money, is a shared value and a widespread practice in the countries on which this research focuses (Lahusen and Grasso, 2018). Thus, if we assume volunteerism as an indicator of social solidarity at the interpersonal level (Hustinx and Lammertyn, 2000; Valastro, 2012), we can assert that Denmark, France, Germany, Greece, Italy, Poland, Switzerland and the UK host a number of forms of horizontal solidarity. This paints a rather rich European horizontal way towards solidarity.

Finally, in decentralised states, subsidiarity allows for interconnectivity between the different tiers of government, making the significance of solidarity relations among all territorial entities emerge. The importance of territorial solidarity is taken into consideration in the cases of Germany, Italy, the UK and Switzerland. In all these jurisdictions, the very structure of the decentralised (federal, regional or cantonal) state relies on the mechanism of power sharing (which assumes different political and legal forms, structures and mechanisms in the different countries) that enables mediation between sub-national and national interests, needs, resources and competences. However, in none of these countries is the equilibrium between diversity, autonomy and solidarity a simple one, and the crisis has exacerbated several elements of this difficult balance. The British and the Italian cases represent the two most critical aspects of territorial solidarity: the very respect of the pactum unionis among sub-national entities and the exacerbation of difference to the detriment of equality in rights enforcement which questions the solidaristic dimension of decentralisation.

In the UK, the solidarity-creation mechanisms between sub-national entities (Scotland, Wales, England, and Northern Ireland) have been seriously challenged in the past few years by political and political-economic issues. These challenges seem to be a catalyst for the robust revival of 
sub-national solidarities against the British one. The devolution of power occurring from the end of the 1990s has come under intense scrutiny in recent years in terms of its capacity to allow sub-national communities to have their voice and interests represented by British decision-making. As a consequence, in Scotland in 2014, a referendum took place for one of the constituting nations of the UK to become independent. Although the vote upheld the will of Scottish people to remain part of the United Kingdom, this was a very strong attempt to reshape the boundaries, and even the content, of territorial solidarity. Even though not directly connected with the Scottish national question, the British people put another form of supranational solidarity under pressure as a legitimate system of redistributing resources across the continent: solidarity based on the European Union. In June 2016 they voted to leave the European Union - a dramatic outcome.

In Italy since the 1990s, there has been a significant devolution of functions to regions in the field of welfare, which has radically changed the relationship between the central government, the regional governments, and local governments according to the principle of subsidiarity. The economic crisis had the effect of modifying and reinforcing the role of regional governments in new strategic policy-making and service delivery to temper both the direct effect of the crisis and the impact of national retrenchment measures. Regional responsibilities in the field of social policies have become so important that scholars argue that Italy has moved from welfare state to welfare regions (Ferrera, 2008). This process has exacerbated existing differences, especially between northern and southern regions, that remain more strongly marked by high rates of poverty, unemployment, social exclusion, and whose regional governments have proved to be less proactive in counterbalancing the worst effects of the crisis, especially in the field of unemployment. The gap is not only measurable in terms of per capita income, but also in terms of well-being and opportunity gaps (Cersosimo and Nisticò, 2013). The paradox is that the regions most severely hit by the crisis were the most vulnerable ones, and the most severely hit populations were the most marginalised - another dramatic failure of territorial solidarity.

\subsection{TALKING ABOUT SOLIDARITY ... IMMIGRATION AND ASYLUM, UNEMPLOYMENT AND DISABILITY ${ }^{3}$}

Principles and rules deriving from the European Union legislation and policies should provide a common normative framework in the fields of 
unemployment, disability and immigration/asylum in EU member states. Nonetheless, the comparative analysis of the seven EU member states plus Switzerland ${ }^{4}$ shows that national principles, legislation and policies in these areas remain highly country-specific. Moreover, even at the national level there is often a lack of consistency. Disability legislation and policies, for example, are generally characterised by internal fragmentation and, in decentralised states, they are even influenced by the regional or federal organisation of the competences.

In many European countries the economic and refugee crises of past years have had a considerable impact on the legal entrenchment of the solidarity principle in the three policy domains of our analysis and its implementation in administrative practice. Across Europe, this impact has been felt differentially, depending on each country's specific crisis experience. The transposition of the constitutional solidarity principle into specific legislation and policies is not simple, and in several cases, there are evident discrepancies between the solidaristic approach embodied in the constitution and specific laws, regulations and policies violating it. As already highlighted, courts may intervene and quite often they do so, reaffirming the overarching constitutional value of solidarity, but this has not prevented dramatic welfare and social security retrenchment measures and a generalised tightening of migration laws.

Very seldom is solidarity expressly named as the leading principle in any of the framework legislation in the policy domains of disability, unemployment/asylum and migration across the eight countries focused on in the present research. Interestingly, from being a fundamental value at the constitutional level, solidarity seems to have become a recessive one at the level of legislation.

Nonetheless, solidarity is of relevance for rights and entitlements in disability, migration/asylum and unemployment law to the extent that it can be derived from other basic constitutional rights and principles, such as equality and anti-discrimination legislation, with few exceptions (e.g. solidarity contracts in Italy and Switzerland). For instance, in Germany it can be derived from the constitutional vision of humanity, the fundamental rights, the welfare state principle, equal treatment, equal participation, and equal opportunities. The right to live a life of human dignity stands above all, and all other rights are subordinate to it. This also means that rights have to be interpreted in the light of the overriding right to a dignified life. Thus, irrespective of the missing explicit reference to solidarity, German law still foresees a broad range of instruments and mechanisms to support the unemployed, asylum seekers and disabled people. And yet, some degree of vagueness in determining the exact significance and legal impact of these principles opens the door for policy-making to downplay the role of 
solidarity and to increase the conditionality of solidarity within vulnerable groups. This has happened particularly in the asylum and unemployment fields in the past few years. Moreover, laws and their administrative implementation are not always perceived by civil society as sufficient to meet solidarity expectations. Indeed, recent policy reforms have shown that solidarity remains highly contested and subject to political struggles between different interest groups in society, even in a country with good economic performance and low unemployment like Germany (Zschache, 2018).

In other countries, such as Greece, although solidarity and the social welfare state are clearly defined in the constitution as a duty of the Greek state towards its citizens, there is mounting evidence that the recent policy options are progressively eroding their normative foundation and practical exercise. After several years of recession, Greece has adopted painful policy choices with regards to wage and pension cuts, labour relations, layoffs and social policies. Failure to protect the weaker, vulnerable population groups most severely hit by the country's multiple crises suggests that solidarity is under stress in Greece. The weakening of solidarity policies for the social protection of people with disabilities, the unemployed, migrants, newly arrived refugees and asylum seekers has gone hand in hand with increased retrenchment, severity of sanctions and welfare conditionality (Mexi, 2018).

Indeed, the process of translating the constitutional principle (either directly or indirectly enforced) into specific legislation and policies is more complex than expected and varies across countries and policy domains.

\subsubsection{Solidarity in Disability Legislation and Policies}

In the frame of the EU approach mainly based on non-discrimination measures (Di Napoli and Russo, 2018), Danish, French, German, Greek, Italian, Polish, Swiss and British disability laws pursue social integration and equality combining typical anti-discrimination measures, proactive integration tools (e.g. social inclusion at school and in the labour market) with social assistance.

People with disabilities have suffered significant reductions of disability grants and allowances due to the crisis in all countries except Germany (Lahusen and Federico, 2018). The introduction of a system of meanstesting for services and benefits in several countries and reforms of the welfare system generally have implied a further increase in the vulnerability of people with disabilities. This occurred especially during the first years of the crisis, even in countries not strongly economically affected such as Denmark, Switzerland and Poland. Disability is one of the typical fields where the notions of intersectionality and multiple discrimination have become very 
relevant (Soder, 2009; Lawson, 2016), which means that disadvantages in the intersection between disability and, for example, unemployment, gender, race, class, etc. are likely to become more severe, and this is why austerity measures tend to have a stronger impact on people with disabilities.

In a first group of countries (Germany, France, Italy, Denmark and Greece) there have not been significant reforms, whereas in the UK, Switzerland, and Poland a number of reforms have been upheld, not touching the principles, but reviewing the mechanisms for accessing benefits. In Poland, indeed, there has been relevant legal activism in order to align with European standards, which has meant an enhancement of rights' guarantees for Polish people with disabilities. Moreover, the concomitant adoption of the International Convention on the Rights of Persons with Disabilities in 2006 has entailed innovative approaches to disability, which means that in the time-frame of the crisis, paradoxically, in terms of legal principles and values, law reforms have tended to enhance the level of rights and guarantees (Petelczyc, 2018).

Nonetheless, the crisis has exacerbated the process of socio-spatial production of legal peripheries (Febbrajo and Harste, 2013) in the field of disability, where contemporary discourse of inclusion and tolerance of diversity is at odds with the real guarantee of fundamental rights, regarding the relationship with the democratic institutions and public administration services. While formally entrenched in legal documents, basic human rights are systematically denied by the lack of resources, and those same rights then become the terrain where exclusion is de facto widespread and strong.

Interestingly, in most countries, the main concerns regarding the disability field do not lie in the lack of legislation, but in its implementation. In Italy, for instance, the legal framework is in line with the most progressive European countries. In some fields, Italy has been (and sometimes still is) ground-breaking, as with the example of disabled pupils' integration in schools. What remains highly problematic is the actual implementation of existing legislation because of a lack of resources and political and administrative will to do so (Federico and Maggini, 2018). But this is true even for a country like Germany, where the effective enforcement of guarantees and the rights of disabled persons is often a question of the quality of administrative practice at the levels of national state, the single federal states, local authorities and benefit providers, and the assertiveness of individual claimants (Welti, 2010: 27; Kuhn-Zuber, 2015).

\subsubsection{Solidarity in Unemployment Laws and Policies}

The impact of the crisis on the quantitative and qualitative levels of employment has put heavy responsibility on European institutions' capacity given 
that Art. 145 TFEU states that "the Union shall contribute to a high level of employment by encouraging cooperation between Member States and by supporting and, if necessary, complementing their action". Despite the fact that EU competence in this field relies primarily on coordination of national policies and legislation, EU legislation and policy have developed along two salient issues: social protection of workers and social rights. Human rights play a key role within the EU coordination of national employment policies in times of crisis: all actions of EU institutions and member states shall comply with them, as well as with the European Social Charter of the Council of Europe (Di Napoli and Russo, 2018). However, the potential role of European institutions is still undeveloped, and the implementation of these principles has fallen short of people's expectations.

At the member state level, the 2008 global economic crisis had very different effects in terms of unemployment: some countries were severely hit by the economic and financial crisis, especially southern countries, but conversely, in Germany, Switzerland, and, partially, in Poland, the crisis had a more modest impact. The picture of policy and legislative responses in the field of unemployment shows also differentiated patterns which, nonetheless, do not necessarily adhere to the crisis effect. The crisis has been seen as an opportunity to address historical weaknesses in the labour market in some countries (as was the case in Italy and Greece), whereas in other countries it was more an "excuse" to pursue a politically oriented agenda (in e.g. Poland, France and the UK). In all countries, however, we detected a general tendency towards policy changes emphasising flexibilisation of labour relations, conditionality for welfare and unemployment benefits and 'activation' elements, in accordance with the broader supply-focused trend characterising European unemployment policies throughout the 1990s and 2000s. And against this trend, employment and unemployment remain highly contested terrains, especially in the countries where the most radical reforms have been upheld (Federico, 2018). Solidarity is a recessive value in current unemployment/labour legislation, even though in this domain it is overtly named, for example, in solidarity contracts in Italy and in Switzerland and in solidarity gradual pre-retirement contracts in France.

\subsubsection{Solidarity in the Field of Migration Legislation and Policies}

The economic crisis was followed by a refugee crisis that especially affected Mediterranean countries like Italy and Greece. The EU legal framework in this field is pivotal: the principle of solidarity has a special role in the common policies of asylum and immigration, set forth respectively in Arts 
78 and 79 of the TFEU (Favilli, 2018). This is due to Art. 80 TFEU which meaningfully provides that these policies and their implementation shall be governed by the principle of solidarity and fair sharing of responsibility, including its financial implications, between the member states. However, the principle of solidarity in immigration and asylum policies also includes the relationship between the EU and its member states, on the one hand, and between the EU, its member states and individuals, especially those escaping persecution and war and looking for asylum in Europe, on the other hand. Indeed, this is the sole interpretation, which is in harmony with the values enshrined by Arts 2 and 3, para. 5 of the TEU, according to which, "In its relations with the wider world . . it shall contribute to peace, security, the sustainable development of the Earth, solidarity and mutual respect among peoples, free and fair trade, eradication of poverty and the protection of human rights, in particular the rights of the child, as well as to the strict observance and the development of international law, including respect for the principles of the United Nations Charter." According to this interpretation, solidarity should apply both to the relationship among member states and to the relations among peoples inside and outside the European territory. It expresses a model of society that should fight against discrimination, violence and unfairness towards disadvantaged people and should actively promote minimum standards of dignity for all human beings. However, moving from theory to practice, the effectiveness of such fundamental provisions is problematic.

Immigration and asylum laws were generally amended during the timeframe of the research, adopting more restrictive measures, except in Poland and Greece. This occurred regardless of the country's actual involvement in the migratory crisis, signalling a politicisation of this policy domain and the increasing importance of populist claims in this regard (Boswell et al., 2011; Van der Brug et al., 2015). This has been confirmed by the firm Polish refusal to welcome refugees and asylum seekers according to the burden-sharing approach of the European Union, a refusal that has led to sanctions by the European Commission who launched infringement procedures against Poland (and Hungary and the Czech Republic) in June 2017 for not having fulfilled their obligations to host relocated migrants from Italy and Greece.

The importance of the migration waves has been claimed as political justification for restrictive legislation and policies in Germany and in Italy, but the Greek case, where there were no severe restrictions in legal access to the country, demonstrates that, even under very critical conditions, the legal response may assume different tones (Mexi, 2018). Furthermore, as in the cases of Denmark, Switzerland, the UK and France, the real numbers of people involved in either the refugee or the economic crises are easily 
overlooked in the political debate, confirmed by a number of research papers and studies (e.g. Van der Brug et al., 2015; Geddes and Scholten, 2016). Moreover, the security trend of legislative and policy reforms has been intensified by a lack of material resources and slow policy implementation, especially in those countries most severely involved with and affected by massive influxes of refugees and migrants.

Finally, little reference, if any at all, is made to solidarity. There are other keywords often mentioned in this field, such as fundamental rights, human dignity and social integration, but solidarity, with its distinctive significance, is absent from the legal discourse and, curiously, it appears in media and popular language to identify a crime in France. On the contrary, it has been the watchword of pro-migrant movements and organisations, as is illustrated in the chapters in this volume devoted to civil society organisation analysis. Nonetheless, solidarity has not been sufficiently evocative and provocative to build a potent counternarrative.

\subsection{SOLIDARITY . . IT DOES SOUND LIKE A WHISPER}

Solidarity can be portrayed as an hourglass: its broad and solid entrenchment at both constitutional and EU treaties level on top; an equally important spectrum of solidarity practices at the level of civil society at the bottom; the two connected through a bottleneck of legislation and policies that are at peace neither with the former nor with the latter.

All countries involved in the present research, in fact, are characterised by complex webs of solidarities, and the same applies to the legal and policy framework at the European Union level. Solidarity is the EU's intimate component: it is indicated as a key-value in its founding treaties both as a general principle and as a norm guiding mutual support among member states and peoples during specific circumstances such as natural or man-made disasters. These multiple solidarities are sometimes imposed by legal frameworks, while at other times the legal frameworks accommodate and recognise existing solidarity ties and practices, and on other occasions, laws and policies result in counter-solidarity measures.

The courts have played a significant role, admittedly with a certain degree of ambiguity in some jurisdictions (at the level of the EU, the judgments rendered by CJEU in the Brey and Dano cases show how EU case-law fluctuates between two "visions" of solidarity, as already mentioned (Thym, 2015)), in mitigating the most severe austerity measures, using solidarity as a valiant constitutional paradigm. But courts' intervention and civil activism, as illustrated in other chapters of this volume, have not prevented 
a further liberalisation of the labour market, the redefinition of the role of the unions and the reforms of retirement age in the field of unemployment. In the field of immigration and asylum, laws have been generally amended, adopting more restrictive measures. Concerning disability, the crisis has led to a reduction of grants and allowances and to the introduction of a system of means-testing for services and benefits. Moreover, the reforms of the welfare system have generally meant an increase in the vulnerability of people with disability.

Has solidarity resisted the crisis crush test? In our analysis, we have tried to free solidarity from the rhetoric often associated with the idea, and to understand the effective potency of the notion. In all the three policy domains, solidarity has been a recessive value against the imperative of the market (in the field of unemployment), of the securisation discourse (in the field of migration) and of welfare retrenchment (in the field of disability). And even in the field of disability, where all our country analyses have highlighted a strong entrenchment of solidarity in the legal framework, the implementation of the laws remains highly problematic, and this seriously jeopardises people's rights and dignity, and undermines solidarity.

The presence per se of solidarity in the constitutions or in the EU treaties does not guarantee the solidaristic quality of national and European laws and policies. During the crisis law-makers and policy-makers at national and EU level decided to privilege other values. Laws and policies entrenched in those years bear little of the various meanings of solidarity, if any at all. The conclusion of this critical discussion is pessimistic: despite the need for solidarity, in both material and symbolic terms, and despite civil society claims for solidarity-based policy-making, political decisions have taken different directions. But constitutions and treaties are documents deemed to persist in time, and solidarity is not solely the virtue of hard times. During the crisis, courts' legal reasoning and public and scientific debates have unveiled multiple dimensions of solidarity and they have highlighted diverse policy domains where solidarity may disclose its still latent potency. Solidarity has been just like a whisper, but the crisis has enriched this whisper with new, interesting and, hopefully, more effective tones, which remain one of the few positive legacies of the hard times engendered by the crisis.

\section{NOTES}

1. Freely inspired by the lyrics of "Talkin" 'bout a Revolution", a song by Tracy Chapman.

2. Due to the supranational nature of the EU legal system, at this level solidarity is embedded in two dimensions: the relationship between member states (horizontal dimension) 
that is evoked in a number of articles of the treaties - for example, Art. 3 of the TEU, enunciating the objectives of the Union, declares that the Union "shall promote economic, social and territorial cohesion, and solidarity among Member States" - and the relationship between the states and their subjects, i.e. the individuals (vertical dimension), which appears in the Preamble of the TEU stating that the Union aims are to "deepen the solidarity between their peoples while respecting their history, their culture and their traditions".

3. For the rationale underlying the selection of the three policy domains, please refer to Lahusen in Chapter 1 of the present volume.

4. Research on the EU impact on Swiss law and policy is widely available. Examples of influence include the so-called autonomous adaptation; multilateral agreements; passing of international treaties; and the comparative law method. For insights, see Epiney, 2009; Jenni, 2014.

\section{REFERENCES}

Apostoli, A. (2012). La svalutazione del principio di solidarietà: crisi di un valore fondamentale per la democrazia. Milan: Giuffrè.

Blais, M. C. (2007). La Solidarité. Historie d'une Idee. Paris: Gallimard.

Bobbio, N. (1990) L'età dei diritti. Turin: Einaudi.

Boswell, C., Geddes, A. and Scholten, P. (2011). The role of narratives in migration policy-making: a research framework. The British Journal of Politics \& International Relations, 13(1): 1-11.

Brunkhorst, H. (2005). Solidarity: From Civic Friendship to a Global Legal Community. Cambridge, MA: MIT Press.

Cersosimo, D. and Nisticò, R. (2013). Un paese disuguale: il divario civile in Italia. Stato e mercato, 33(2): 265-300.

Cippitani, R. (2010). La solidarietà giuridica tra pubblico e privato. Perugia: ISEGIst Studi Econ e Giu.

Cyr, H. (2014). Autonomy, subsidiarity, solidarity: foundations of cooperative federalism. Constitutional Forum, 23(4): 20-40.

de Búrca, G. and Weiler, J. H. H. (eds) (2011). The Worlds of European Constitutionalism. Cambridge: Cambridge University Press.

di Napoli, E. and Russo, D. (2018). Solidarity in the European Union at times of crisis: towards "European solidarity"? In V. Federico and C. Lahusen (eds), Solidarity as a Public Virtue? Law and Public Policies in the European Union. Baden-Baden: Nomos, pp. 195-248.

Epiney, A. (2009). How does the European Union law influence Swiss law and Swiss policies? In S. Nahrarth and F. Varone (eds), Rediscovering Public Law and Public Administration in Comparative Policy Analysis: A Tribute to Peter Knoepfel. Bern: Haupt, pp. 179-95.

Esping-Andersen, G. (1990). The Three Worlds of Welfare Capitalism. Cambridge: Polity Press.

Favilli, C. (2018). La politica dell'Unione in materia d'immigrazione e asilo. Carenze strutturali e antagonismo tra gli Stati membri. Quaderni costituzionali, 38(2): 361-88.

Febbrajo, A. and Harste, G. (2013). Law and Intersystemic Communication: Understanding 'Structural Coupling'. London: Routledge.

Federico, V. (2018). Conclusion: solidarity as a public virtue? In V. Federico and 
C. Lahusen (eds), Solidarity as a Public Virtue? Law and Public Policies in the European Union. Baden-Baden: Nomos, pp. 495-541.

Federico, V. and Maggini, N. (2018). Disability, unemployment and immigration: does solidarity matter at the times of crisis? In V. Federico and C. Lahusen (eds), Solidarity as a Public Virtue? Law and Public Policies in the European Union. Baden-Baden: Nomos, pp. 361-93.

Ferrera, M. (1996). The 'Southern model' of welfare in social Europe. Journal of European social policy, 6(1): 17-37.

Ferrera, M. (2005). The Boundaries of Welfare: European Integration and the New Spatial Politics of Social Protection. Oxford: Oxford University Press.

Ferrera, M. (2008). Dal welfare state alle welfare regions: la riconfigurazione spaziale della protezione sociale in Europa. La Rivista delle Politiche Sociali, 3(2008): 17-49.

Geddes, A. and Scholten, P. (2016). The Politics of Migration and Immigration in Europe. London: Sage.

Giubboni, S. and Costamagna, F. (2017). Solidarity as a shield. The burden of intra-EU mobility on national welfare systems between myth and reality. Paper presented at the Villa Vigoni Colloquium. Solidarity as a contested terrain: ItaloGerman experiences in the European frame. 27-9 November 2017.

Habermas, J. (2013). Democracy, solidarity and the European crisis. https://www. pro-europa.eu/europe/jurgen-habermas-democracy-solidarity-and-the-europeancrisis/?print=print.

Hustinx, L. and Lammertyn, F. (2000). Solidarity and volunteering under a reflexive-modern sign: towards a new conceptual framework. ISTR's Conference Working Papers. Presented at the Fourth ISTR's international conference "The Third Sector: For what and for whom".

Jenni, S. (2014). Europeanization of Swiss law-making: empirics and rhetoric are drifting apart. Swiss Political Science Review, 20(2): 208-15.

Kuhn-Zuber, G. (2015). Soziale Inklusion und Teilhabe. Die Reform der Eingliederungshilfe unter Berücksichtigung des Rechts auf unabhängige Lebensführung und Einbeziehung in die Gemeinschaft aus Art. 19 BRK. Sozialer Fortschritt, 64(11): 259-66.

Lahusen, C. and Federico, V. (2018). Introduction. In V. Federico and C. Lahusen (eds), Solidarity as a Public Virtue? Law and Public Policies in the European Union. Baden-Baden: Nomos, pp. 11-32.

Lahusen, C. and Grasso, M. T. (2018). Solidarity in Europe - European Solidarity: an introduction. In C. Lahusen and M. T. Grasso (eds), Solidarity in Europe: Citizens' Responses in Times of Crisis. Basingstoke: Palgrave Macmillan, pp. 1-18.

Lanceiro, R. (2017). Dano and Alimanovic: the recent evolution of CJEU case-law on EU citizenship and cross-border access to social benefits. UNIO - EU Law Journal, 3(1): 63-77.

Lawson, A. (2016). European Union Non-Discrimination Law and Intersectionality: Investigating the Triangle of Racial, Gender and Disability Discrimination. London: Routledge.

Mexi, M. M. (2018). Greece in times of multiple crises: solidarity under stress? In V. Federico and C. Lahusen (eds), Solidarity as a Public Virtue? Law and Public Policies in the European Union. Baden-Baden: Nomos, pp. 337-60.

Montgomery, T. and Baglioni, S. (2018). The United Kingdom. In V. Federico and C. Lahusen (eds), Solidarity as a Public Virtue? Law and Public Policies in the European Union. Baden-Baden: Nomos, pp. 179-91. 
Onida, V. (2003). Viva Vox Constitutionis. Temi e tendenze nella giurisprudenza costituzionale. Milan: Giuffré.

Petelczyc, J. (2018). Disability, unemployment, immigration: does disability matter in times of crisis? The Polish case. In V. Federico and C. Lahusen (eds), Solidarity as a Public Virtue? Law and Public Policies in the European Union. Baden-Baden: Nomos, pp. 395-419.

Rodotà, S. (2014). La Solidarietà. Rome: Laterza.

Ross, M. G. (2010). A new constitutional paradigm for the EU? In M. G. Ross and Y. Borgmann-Prebil (eds), Promoting Solidarity in the European Union. New York: Oxford University Press, pp. 23-45.

Scruggs, L. and Allan, J. (2006). Welfare state decommodification in 18 OECD countries. Journal of European Social Policy, 16(1): 55-72.

Serre, M. and Palier, B. (2004). France: moving reluctantly in the OECD's direction. In K. Armingeon and M. Beyeler (eds), The OECD and European Welfare States. Cheltenham, UK and Northampton, MA, USA: Edward Elgar Publishing, pp. 101-12.

Soder, M. (2009). Tensions, perspectives, themes in disability studies. Scandinavian Journal of Disability Research, 11(2): 67-81.

Supiot, A. (ed.) (2015). La solidarité: enquête sur un principe juridique. Paris: Odile Jacob.

Taylor-Gooby, P. (2013). The Double Crisis of the Welfare State and What We Can Do about It. Basingstoke: Palgrave Macmillan.

Thym, D. (2015). The elusive limits of solidarity: resistance rights of and social benefits for economically inactive Union citizens. Common Market Law Review, 52(1): $17-50$.

Tuori, K. (2015). European Constitutionalism. Cambridge: Cambridge University Press.

Valastro, A. (2012). Volunteerism, solidarity and social capital. Italian Sociological Review, 2(1): 24-32.

Van der Brug, W., D’Amato, G., Ruedin, D. and Berkhout, F. (eds) (2015). The Politicisation of Migration. London: Routledge.

Welti, F. (2010). Grund-und Menschenrechte behinderter Menschen Heilpädagogik im sozialen Rechtsstaat. In Bundesverband Heilpädagogik (eds), Weiterdenken Heilpädagogik. Menschen: Rechte. Tagungsbericht 2009. Berlin: BHP-Verlag, pp. 11-35.

Zschache, U. (2018). Disability, unemployment, immigration: the implicit role of solidarity in German legislation. In V. Federico and C. Lahusen (eds), Solidarity as a Public Virtue? Law and Public Policies in the European Union. Baden-Baden: Nomos, pp. 303-36. 